\title{
FIRST TAIWANESE RECORDS OF THE LONG-BARBEL GOATFISH, PARUPENEUS MACRONEMUS (ACTINOPTERYGII: PERCIFORMES: MULLIDAE), WITH THE NORTHERNMOST RECORD IN THE PACIFIC OCEAN
}

\author{
Keita KOEDA ${ }^{1 *}$ and Hsuan-Ching $\mathrm{HO}^{1,2}$ \\ ${ }^{1}$ National Museum of Marine Biology \& Aquarium, Checheng, Pingtung, Taiwan \\ ${ }^{2}$ Institute of Marine Biology, National Dong Hwa University, Pingtung, Taiwan
}

Koeda K., Ho H.-C. 2018. First Taiwanese records of the long-barbel goatfish, Parupeneus macronemus (Actinopterygii: Perciformes: Mullidae), with the northernmost record in the Pacific Ocean. Acta Ichthyol. Piscat. 48 (3): 285-288.

\begin{abstract}
In total, 31 species of genus Parupeneus are recognized, and 13 of these have been recorded from Taiwanese waters. Although the long-barbel goatfish, Parupeneus macronemus (Lacepède, 1801) has been previously known from western Pacific Ocean north to Philippines without voucher specimens, no records were reported from Taiwan. The main objective of this paper is to document the presence of P. macronemus in the waters of Taiwan. Two specimens (173.1 and $177.1 \mathrm{~mm}$ standard length) of long-barbel goatfish were collected from southern Taiwan on 2017. The morphology and fresh coloration of the collected specimens are herein described. The majority of the morphological characters agree well with previous descriptions of P. macronemus: e.g., total number of gill rakers $35-36$; barbel length $83.1 \%-86.8 \%$ in head length; black stripe from eye along lateral line to anterior part of caudal peduncle; a roundish black blotch larger than eye on middle side of caudal peduncle; basal half of second dorsal fin black. Therefore the goatfish specimens from southern Taiwan are identified as Parupeneus macronemus. The presently described specimens represent the first record for Taiwan, as well as the northernmost record of this species in the Pacific Ocean. In addition, the presently described specimens constitute the first reliable record of the species in the north-western Pacific Ocean.
\end{abstract}

Keywords: taxonomy, distribution, coral reef, goatfish, Parupeneus diagonalis

\section{INTRODUCTION}

The genus Parupeneus Bleeker, 1863, belonging to the family Mullidae which is known to accommodate currently 31 valid species (Fricke et al. 2018), and 13 of these, Parupeneus barberinoides (Bleeker, 1852), Parupeneus barberinus (Lacepède, 1801), Parupeneus biaculeatus (Richardson, 1846), Parupeneus chrysopleuron (Temminck et Schlegel, 1843), Parupeneus ciliatus (Lacepède, 1802), Parupeneus crassilabris (Valenciennes, 1831), Parupeneus cyclostomus (Lacepède, 1801), Parupeneus heptacanthus (Lacepède, 1802), Parupeneus indicus (Shaw, 1803), Parupeneus multifasciatus (Quoy et Gaimard, 1825), Parupeneus pleurostigma (Bennett, 1831), Parupeneus spilurus (Bleeker, 1854), Parupeneus trifasciatus (Lacepède, 1801), have been recorded from Taiwanese waters (Shen and Wu 2011).

Two specimens of Parupeneus macronemus (Lacepède, 1801) were recently collected off Kenting, southern Taiwan. This species was previously recorded from north to Philippines in western Pacific, thus the present specimen represents the first Taiwanese record and the northernmost record of $P$. macronemus. Therefore, the morphology and fresh coloration of the collected specimens are herein described.

\section{MATERIALS AND METHODS}

Counts and measurements follow Randall (2004). Measurements were made to the nearest $0.1 \mathrm{~mm}$ with needle-point callipers. Standard length and head length are abbreviated as SL and HL, respectively. The morphological description is based on the specimen collected from Taiwan. The specimens of Parupeneus macronemus examined in this study are deposited at National Museum of Marine Biology \& Aquarium (NMMB-P), Checheng, Pingtung, Taiwan.

Specimens examined. NMMB-P26623, $173.1 \mathrm{~mm}$ SL, off Kenting, purchased at Hengchun market, 27 July 2017, coll. K. Koeda, A. Koeda, and H.-C. Ho; NMMB-P 27477, $177.1 \mathrm{~mm}$ SL, off Kenting, purchased at Hengchun market, 25 November 2017, coll. C.-H. Lin.

\section{RESULTS}

\footnotetext{
Correspondence: Dr. Keita Koeda, 944 屏東縣車城鄉後灣村後灣路2號, Taiwan, phone: (+866) 966543754, e-mail: (KK) hatampo@gmail.com, (HH) hohc@nmmba.gov.tw.
} 
Parupeneus Bleeker, 1863

Parupeneus macronemus (Lacepède, 1801) 太帯海緋鯉 (New Taiwanese name)

Fig. 1, Table 1

Mullus macronemus (Lacepède, 1801): 383, 404, pl. 13, fig. 2 (type locality: not given).

Mullus lateristriga Cuvier in Cuvier et Valenciennes, 1829: 463 (unnecessary new name for Mullus macronemus).

Parupeneus macronema: Bleeker, 1875: 24 (Indonesia); Allen et al. 2003: 399, unnumbered figs. (Indo-Pacific Ocean).

Parupeneus macronemus: Randall, 2004: 38, pl. 4B; Allen and Erdmann 2012: 507, unnumbered figs. (Indo-Pacific Ocean). Description of Taiwanese specimens. Counts and measurement of present specimens are given in Table 1. Body elongate, deepest at origin of first dorsal fin; depth of caudal peduncle slightly less than half of greatest body depth; head moderately pointed; dorsal profile moderate rising from snout to first dorsal-fin origin, slightly concave at snout, thereafter lowering to caudal peduncle; ventral profile lowering from lower-jaw tip to origin of pectoral fin, thereafter rising from anal-fin origin to caudal peduncle. Caudal peduncle well compressed. Mouth small, maxilla not reach vertical at front of orbit; small conical teeth on both jaws, placed in one outer row and more irregularly behind in front of jaws, and on single row more posteriorly; no teeth on roof of mouth; anterior nostril small vertically elliptical opening middle of snout and anterior margin of eye; posterior nostril just anterior of orbit; barbel long. Longest gill raker on first arch about $2 / 3$ of longest gill filament; single flat spine at posterior edge of operculum at lower-eye level. Scales very finely ctenoid; head fully scaled; fins naked except base of caudal fin; origin of first and second dorsal fin vertical at 4th and 13th lateral line scale, respectively; origin of anal fin vertical at origin of second dorsal

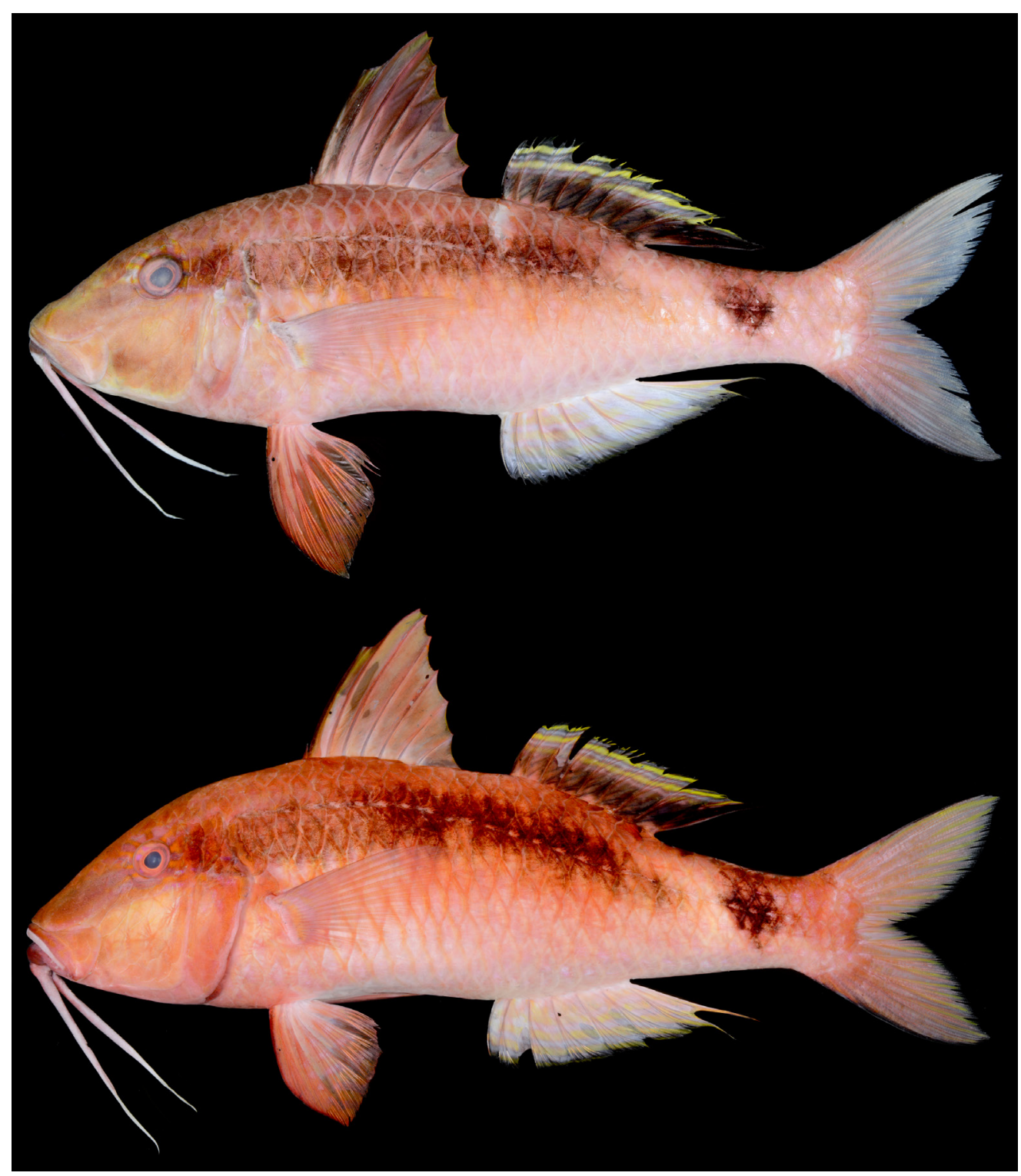

Fig. 1. Fresh specimens of Parupeneus macronemus from Kenting, southern Taiwan; upper: NMMB-P26623, $173.1 \mathrm{~mm}$ SL; lower: NMMB-P27477, $177.1 \mathrm{~mm} \mathrm{SL}$ 
fin; uppermost point of pectoral-fin insertion, vertical Lateral line following contour of back; pored scales of at origin of pelvic fin, anterior to vertical at origin of lateral line with many branched tubules.

first dorsal fin; pectoral fin reaching vertical at posterior Colour when fresh. Body, head, greyish red dorsally, margin of first dorsal fin base; depressed pelvic fin not whish pink ventrally; barbel white. Black stripe, wider reaching anus. Depressed pelvic fin not reaching anus. than eye diameter, running from posterior margin of eye Caudal fin triangular, posterior margin well forked. along lateral line to anterior part of caudal peduncle; roundish black blotch larger than eye on middle side of

Table 1

Counts and measurements of Parupeneus macronemus from the present study and from Randall (2004)

\begin{tabular}{|c|c|c|c|}
\hline & NMMB-P26623 & NMMB-P27477 & Randall 2004 \\
\hline Standard length (SL) [mm] & 173.1 & 177.1 & $35.0-245.0$ \\
\hline \multicolumn{4}{|l|}{ Counts } \\
\hline Dorsal-fin rays & VIII, 9 & VIII, 9 & - \\
\hline Anal-fin rays & I, 7 & $\mathrm{I}, 7$ & - \\
\hline Pectoral-fin rays & 16 & 17 & $15-17$ \\
\hline Pelvic-fin rays & $\mathrm{I}, 5$ & $\mathrm{I}, 5$ & - \\
\hline Principal caudal-fin rays & $\mathrm{i}+13+1$ & $\mathrm{i}+13+1$ & - \\
\hline Lateral-line scales & 27 & 28 & - \\
\hline Scales above lateral line to origin of first dorsal fin & $21 / 2$ & $21 / 2$ & - \\
\hline Scale below lateral line to origin of anal fin & 7 & 7 & - \\
\hline Circumpeduncular scales & 14 & 14 & - \\
\hline Middle pre-dorsal-fin scales & 13 & 13 & - \\
\hline Median pre-pelvic-fin scales & 8 & 8 & - \\
\hline Gill rakers & $8+28=36$ & $8+27=35$ & $7-9+27-30=34-39$ \\
\hline \multicolumn{4}{|l|}{ Measurements } \\
\hline \multicolumn{4}{|l|}{$\%$ of SL } \\
\hline Body depth & 28.7 & 29.9 & $27.0-30.3$ \\
\hline Body width & 14.6 & 15.6 & - \\
\hline Head length (HL) & 32.0 & 32.7 & $31.3-35.7$ \\
\hline Caudal peduncle depth & 11.3 & 11.5 & - \\
\hline Caudal peduncle length & 22.8 & 24.4 & - \\
\hline Pre-dorsal-fin length & 38.8 & 40.8 & - \\
\hline Pre-anal-fin length & 59.2 & 60.0 & - \\
\hline Pre-pelvic-fin length & 33.0 & 33.7 & - \\
\hline \multicolumn{4}{|l|}{$\%$ of $\mathrm{HL}$} \\
\hline Snout length & 54.4 & 56.9 & $52.6-58.8$ \\
\hline Orbit diameter & 17.8 & 16.5 & - \\
\hline Interorbital width & 26.6 & 28.4 & - \\
\hline Upper jaw length & 39.1 & 40.4 & - \\
\hline Barbel length & 86.9 & 83.2 & $80.0-90.9$ \\
\hline First dorsal-fin spine length & 6.9 & 9.2 & - \\
\hline Second dorsal-fin spine length & 48.1 & 48.3 & - \\
\hline Third dorsal-fin spine length & 68.8 & 67.9 & $57.1-69.0$ \\
\hline Fourth dorsal-fin spine length & 65.3 & 63.3 & - \\
\hline First dorsal-fin soft ray length & 24.7 & 24.5 & - \\
\hline Second dorsal-fin soft ray length & 30.0 & 29.7 & - \\
\hline Eighth dorsal-fin soft ray length & 38.1 & 39.8 & - \\
\hline Ninth dorsal-fin soft ray length & 51.9 & 58.7 & - \\
\hline Anal-fin spine length & 3.4 & 4.9 & - \\
\hline Seventh anal-fin soft ray length & 49.1 & 54.1 & - \\
\hline Caudal fin length & 66.3 & 69.7 & - \\
\hline Caudal fin concavity & 41.9 & 43.1 & - \\
\hline Pectoral fin length & 72.2 & 69.1 & $66.7-76.9$ \\
\hline Pelvic-fin spine length & 46.9 & 41.6 & - \\
\hline Pelvic fin length & 75.6 & 67.3 & $69.0-83.3$ \\
\hline \multicolumn{4}{|l|}{$\%$ of ninth dorsal-fin soft ray length } \\
\hline Eighth dorsal-fin soft ray length & 78.7 & 67.8 & $62.5-80.0$ \\
\hline
\end{tabular}


caudal peduncle; faint white zone extending anterior to peduncle blotch below posterior part of second dorsalfin base. First dorsal and pelvic fins pink with dusky on outer half of fins; basal half of second dorsal fin black, dark pigment continuing to end of last ray and adjacent membrane; outer part of fin with narrow pale blue and yellow 3-5 stripes; anal fin faint yellow with faint narrow pale blue 4-5 stripes; pectoral fin semi-translucent pink; caudal fin pinkish white.

Distribution. Parupeneus macronemus is currently known mainly from the Indian Ocean, and few from the Pacific Ocean: the northern Red Sea and Persian Gulf, south to Natal, east to Indonesia (Randall 2004), and north to Philippines (Herre 1934, 1953), but now from Taiwan (presently reported study).

\section{DISCUSSION}

The majority of morphological characters of the presently described specimens are consistent with the diagnosis of Parupeneus macronemus given by Randall (2004): total gill rakers 35 or 36 ; barbel length $83.1 \%$ HL or $86.8 \%$ HL; eight dorsal-fin soft rays length $67.8 \%$ or $78.7 \%$ in last dorsal-fin soft rays length; body grey to greyish red dorsally, whitish pink ventrally; black stripe from eye along lateral line to anterior part of caudal peduncle; a roundish black blotch larger than eye on middle side of caudal peduncle; a faint white zone extending anterior to peduncle blotch below posterior part of second dorsal-fin base; barbels white; basal half of second dorsal fin black, the dark pigment continuing to end of last ray and adjacent membrane; outer part of fin with narrow pale blue and yellow 3-5 stripes; anal fin faint yellow with faint narrow pale blue 4-5 stripes.

Although $P$. macronemus is a distinctive species, this species is most similar to Parupeneus diagonalis Randall, 2004 which is distributed in the Indian Ocean among the congeners, sharing the black colouration of basal part of second dorsal fin (the black pigment extending to distal end of last membrane), and a single black stripe running on the body side. However, the former can clearly be distinguished from the latter by having a black stripe from upper end of gill opening following lateral line to caudal peduncle (vs. an oblique dark red to black stripe from upper end of gill opening to below rear base of second dorsal fin), a large black blotch on caudal peduncle (vs. no blotch), barbels long, 80.0\%-90.9\% HL (vs. not very long, 64.5\%-74.1\%), eight dorsal-fin soft rays length $62.5 \%-80.0 \%$ in last dorsal-fin soft rays length (vs. 83.3\%-95.2\%), and gill rakers 34-39 (vs. 29-31) (Randall 2004). Parupeneus macronemus most similar to $P$. barberinus in the congeners which distribute in the Pacific Ocean, sharing a single black stripe running on the body side. However, the former can clearly distinguish from the latter by having longer barbels $80.0 \%-90.9 \%$ HL (vs. $62.5 \%-71.4 \%$ ), and second dorsal fin black with blackish basal part (vs. pale coloured) (Randall 2004).

Herre (1934) firstly recorded P. macronemus from Jolo in the Sulu Archipelago as a new record from Philippines on the basis of a specimen, but no data were given for the specimen other than the length of $150 \mathrm{~mm}$. Herre (1953) added the localities of Mindanao, Negros, and Luzon for its distribution, but Randall (2004) mentioned that he could not find the Philippine specimens of this species in museums. However, he also indicated that the species is so distinctive, Herre's $(1934,1953)$ records are probably correct. After this report, no additional records are shown from the Philippines waters. Therefore, the previous northernmost record of $P$. macronemus was from Luzon, Philippines with uncertain reports, and has not been recorded from Taiwanese waters. Therefore, the presently described specimens, collected from southern Taiwan, represent the first record of $P$. macronemus from Taiwan, and it is undoubtedly the northernmost record of the species. In addition, our record from Taiwan shown that the species potentially distributes widely in the western Pacific.

\section{ACKNOWLEDGEMENTS}

We are especially grateful to Dr. C.-H. Lin for providing the specimens. We also greatly appreciate Miss R.-R. Chen and Mrs A. Koeda (NMMB-P) for curatorial assistance. The presently reported study was supported in part by a JSPS Overseas Research Fellowships (29-304) to the first author.

\section{REFERENCES}

Allen G.R., Erdmann M.V. 2012. Reef fishes of the East Indies. Volumes 1-3. Tropical Reef Research, Perth, Australia.

Allen G.R., Steene R., Humann P., Deloach N. 2003. Reef fish identification, tropical Pacific. New World Publication, Jacksonville, FL and Odyssey Publishing, El Cajon, CA, USA.

Fricke R., Eschmeyer W.N., van der Laan R. (eds.) 2018. Catalog of fishes: Genera, species, references. California Academy of Sciences, San Francisco, USA. [Accessed on 12 September 2018.] http://researcharchive.calacademy.org/research/ ichthyology/catalog/fishcatmain.asp

Herre A.W. 1934. Notes on fishes in the Zoological Museum of Stanford University. The Fishes of the Herre Philippine Expedition of 1931. The Newspaper Enterprise Ltd., Hong Kong.

Herre A.W. 1953. Check list of Philippine fishes. Research Report, U.S. Fish and Wildlife Service 20: 1-977.

Randall J.E. 2004. Revision of the goatfish genus Parupeneus (Perciformes: Mullidae), with description of two new species. Indo-Pacific Fishes 36: 1-64, pls. i-xvi.

Shen S.-C., Wu K.-Y. 2011. [Fishes of Taiwan.] National Museum of Marine Biology and Aquarium, Checheng, Taiwan. [In Chinese.]

Received: 26 March 2018

Accepted: 26 April 2018

Published electronically: 30 September 2018 